\title{
Is there a mandelate enzyme complex in Acinetobacter calcoaceticus or Pseudomonas putida?
}

\author{
Mary E. Hoey and Charles A. Fewson* \\ Department of Biochemistry, University of Glasgow, Glasgow G12 8QQ, UK
}

(Received 13 April 1989; revised 11 September 1989; accepted 6 November 1989)

\begin{abstract}
Several methods were used in a vain search for a possible specific, isolable complex of the enzymes involved in the conversion of mandelate into benzoate in Acinetobacter calcoaceticus and Pseudomonas putida. Previous in vivo cross-linking experiments done by other workers with $P$. putida were repeated and slightly extended. Extracts prepared from bacteria that had been treated with dimethylsuberimidate were analysed by ultracentrifugation and gel-filtration chromatography. In confirmation of the original observations, some of the mandelate enzymes were found to be linked to high- $M_{\mathrm{r}}$ material. However, several control enzymes behaved in the same way and only a small proportion of the 'soluble' mandelate enzymes were found in exactly the same fraction as the membranebound L(+)-mandelate dehydrogenase. Similarly, no specific cross-linking was observed in experiments with $A$. calcoaceticus, even when the bacteria were supplied with substrates and cofactors for the mandelate enzymes. There was no evidence for co-fractionation of the mandelate enzymes from extracts that had been prepared in various ways. Treatment of homogenates with antiserum that had been raised against phenylglyoxylate decarboxylase failed to co-precipitate the other mandelate enzymes. Incubation of homogenates with anti-D( - )mandelate dehydrogenase did lead to the removal of some phenylglyoxylate decarboxylase from the supernatant fraction, but this is ascribed to the interaction of phenylglyoxylate decarboxylase with a membrane component other than $D(-)$-mandelate dehydrogenase. Control and cross-linked extracts were analysed by SDS-PAGE followed by immunoblotting with the three antisera. Although there was evidence for the formation of high- $M_{\mathrm{r}}$ species, there was no sign of specific cross-linking of any of the three enzymes to each other. Experiments involving cross-linking with other dimethylimidates and with phenylene dimaleimide all failed to provide evidence for a mandelate complex.
\end{abstract}

\section{Introduction}

Halpin et al. (1981) reported evidence consistent with the idea of physical association of the enzymes of the mandelate pathway in Pseudomonas putida. The experiments involved the cross-linking reagent DMSI. When extracts from control and DMSI-treated $P$. putida were subjected to differential centrifugation, there was a 9- to 25-fold increase in the 'soluble' enzyme activities recovered in the pellet fraction [where most of the membrane-bound $\mathrm{L}(+)$-mandelate dehydrogenase activity was already located] after DMSI treatment. In addition, when extracts from bacteria which had been treated with DMSI in vivo were subjected to gel-filtration chromatography, an extra peak of enzyme activities appeared in the void volume, which in control extracts

\footnotetext{
Abbreviations: DMPI, dimethylpimelimidate; DMSI, dimethylsuberimidate; TPP, thiamin pyrophosphate.
}

had only $\mathrm{L}(+)$-mandelate dehydrogenase activity. This was taken to indicate the possible presence of a high- $M_{\mathrm{r}}$ aggregate of the mandelate enzymes. The cross-linked complex was also studied by ${ }^{13} \mathrm{C}-\mathrm{NMR}$ spectroscopy (Halpin et al., 1981). On oxygenation of the isolated complex, DL- $\left[\alpha^{-13} \mathrm{C}\right]$ mandelate was converted into $\left[\alpha^{-13} \mathrm{C}\right]$ benzoate; $\left[\alpha^{-13} \mathrm{C}\right]$ phenylglyoxylate and $\left[\alpha^{13} \mathrm{C}\right]-$ benzaldehyde were also detected. This confirmed that all the enzymes necessary for the metabolism of mandelate to benzoate were present in the high- $M_{\mathrm{r}}$ material. However, it was also reported that in one experiment, $\left[{ }^{13} \mathrm{C}\right]$ bicarbonate was detected after oxygenation of the isolated complex suggesting that the two enzymes that convert benzoate into catechol were also present in the high $M_{\mathrm{r}}$ material. Some glutamine synthetase was also present in the cross-linked sample.

Acinetobacter calcoaceticus, like $P$. putida, can use mandelate as the sole source of carbon and energy for growth (Fewson, 1988). In A. calcoaceticus, L-mandelate 
is oxidized to phenylglyoxylate by $\mathrm{L}(+)$-mandelate dehydrogenase in the wild-type strain NCIB 8250 and some mutants also have a $D(-)$-mandelate dehydrogenase which allows growth on D-mandelate. $L(+)$-Mandelate dehydrogenase and $D(-)$-mandelate dehydrogenase, which are both membrane-bound flavoproteins, as well as phenylglyoxylate decarboxylase and benzaldehyde dehydrogenase I, are coordinately synthesized and are referred to as the 'mandelate enzymes' (Fewson, 1988). Unlike the enzymes of mandelate metabolism in $P$. putida, the mandelate enzymes of $A$. calcoaceticus have all been purified, partly characterized and antibodies have been raised against them (Allison et al., 1985a, b; Barrowman \& Fewson, 1985; Hoey et al., 1987; Chalmers \& Fewson, 1988).

In the present work, some of the experiments on $P$. putida described by Halpin et al. (1981) have been repeated, extended and the original results largely confirmed. The possibility of some sort of interaction amongst the enzymes of the mandelate pathway in $A$. calcoaceticus was investigated using a variety of techniques. However, the results do not seem to support the notion of a 'mandelate complex' in either A. calcoaceticus or $P$. putida.

\section{Methods}

Organisms. Acinetobacter calcoaceticus mutant strains C1005 [NCIB 11339; constitutive $L(+)$-mandelate dehydrogenase, no $D(-)$ mandelate dehydrogenase], C1123 [NCIB 11456; constitutive $\mathrm{D}(-)$ mandelate dehydrogenase, no $\mathrm{L}(+)$-mandelate dehydrogenase], C1219 [NCIB 11457, constitutive $D(-)$ - and $L(+)$-mandelate dehydrogenase] and $\mathrm{C} 1408$ [NCIB 10789, no $\mathrm{D}(-)$ - or $\mathrm{L}(+)$-mandelate dehydrogenase activities] were derived from the wild-type strain NCIB 8250 (Allison et al., 1985a). Pseudomonas putida wild-type strain NCIB 9494 (strain A3.12) is inducible for the mandelate enzymes (Hegeman, 1966). The wild-type strains were obtained from the National Collection of Industrial Bacteria, Aberdeen, UK.

Growth of bacteria. A. calcoaceticus was maintained and grown in complex medium containing mandelate (Allison et al., 1985a). Inocula were prepared by aseptically transferring $0.1 \mathrm{ml}$ of a stock culture into $50 \mathrm{ml}$ of medium (in $250 \mathrm{ml}$ conical flasks) and grown at $30^{\circ} \mathrm{C}$ with shaking (120 r.p.m.) for 24 h. These cultures were used to inoculate $(2.5 \%, v / v) 400 \mathrm{ml}$ volumes of medium (in 2 litre conical flasks) which were incubated at $30^{\circ} \mathrm{C}$ with shaking for $16 \mathrm{~h}$. The bacteria were then harvested by centrifugation and used immediately.

$P$. putida was grown in minimal medium containing mandelate. This medium was adapted from that used by Hegeman (1966) and contained ( $\left.\mathrm{g} \mathrm{l}^{-1}\right)$ : DL-mandelate, $1.52(10 \mathrm{mM}) ;\left(\mathrm{NH}_{4}\right)_{2} \mathrm{SO}_{4}, 1 ; \mathrm{KH}_{2} \mathrm{PO}_{4}, 3.4$; $\mathrm{Na}_{2} \mathrm{HPO}_{4}, 3.55$; and $2 \mathrm{ml}$ of trace metals solution $1^{-1}$. The trace metals were prepared as described by Beggs \& Fewson (1977). The solution containing mandelate was adjusted to $\mathrm{pH} 6.9$ with $\mathrm{NaOH}$, made to the correct volume with distilled water and autoclaved. Immediately before inoculation, sterile $2 \%(\mathrm{w} / \mathrm{v}) \mathrm{MgSO}_{4} .7 \mathrm{H}_{2} \mathrm{O}\left(20 \mathrm{ml} \mathrm{l}^{-1}\right)$ was added. A stock nutrient broth culture of $P$. putida was inoculated $(0.2 \%)$ into $50 \mathrm{ml}$ of minimal medium containing mandelate and grown for $24 \mathrm{~h}$ at $30^{\circ} \mathrm{C}$ with shaking. This culture was used as the inoculum $(2.5 \%, v / v)$ for $400 \mathrm{ml}$ volumes of medium (in 2 litre flasks) which were incubated at $30^{\circ} \mathrm{C}$ with shaking. These cultures were harvested when the $\mathrm{OD}_{500}$ reached 0.8 (after about $5 \mathrm{~h}$ ).

Disruption of bacteria. For ultrasonic disruption, bacteria were resuspended in the appropriate buffer (usually $50 \mathrm{~mm}$-potassium phosphate buffer, $\mathrm{pH} 7.5)$ to a final concentration of $0.25 \mathrm{~g}$ wet wt $\mathrm{ml}^{-1}$. Portions $(5$ to $7 \mathrm{ml}$ ) in $10 \mathrm{ml}$ glass vials were placed in a chilled brass holder. This was screwed onto the horn of a $13 \mathrm{~mm}$ probe of a Dawe Soniprobe (type 7532A) and lowered into an ice/water slurry. $A$. calcoaceticus was disrupted at $80 \mathrm{~W}$ for $5 \times 30$ s periods alternated with cooling periods of $30 \mathrm{~s}$. $P$. putida was also disrupted at a current of $80 \mathrm{~W}$ but for $3 \times 30 \mathrm{~s}$ periods alternated with cooling periods of $30 \mathrm{~s}$. The homogenates were centrifuged at $15000 \mathrm{~g}$ for $20 \mathrm{~min}$ at $4{ }^{\circ} \mathrm{C}$ in an MSE 18 Highspeed centrifuge to remove intact bacteria and debris.

For disruption in the French press, bacteria were resuspended in an appropriate buffer, usually to a final concentration of $0.5 \mathrm{~g} \mathrm{wet} \mathrm{wt} \mathrm{ml}^{-1}$, and disrupted by one to four passages through a French press (4-3398A; Aminco) at a pressure of $98 \mathrm{MPa}\left(14300 \mathrm{lbf} \mathrm{in}^{-2}\right)$. Intact bacteria and debris were removed by centrifuging the homogenate at $15000 \mathrm{~g}$ for $20 \mathrm{~min}$ at $4^{\circ} \mathrm{C}$ in an MSE 18 Highspeed centrifuge.

In the case of lysozyme treatment, freshly harvested bacteria were washed three times in $50 \mathrm{mM}-\mathrm{Tris} / \mathrm{HCl}$ buffer, $\mathrm{pH} \mathrm{7.8}$, and resuspended

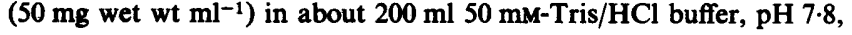
containing $0.6 \mathrm{M}$-sucrose. The suspension was incubated with lysozyme [10 mg (g wet wt) $)^{-1}$ ] for $150 \mathrm{~min}$ at $23^{\circ} \mathrm{C}$, after which spheroplasts were harvested by centrifuging at $15000 \mathrm{~g}$ for $20 \mathrm{~min}$ at $4^{\circ} \mathrm{C}$ in an MSE 18 Highspeed centrifuge. The spheroplasts were washed once by resuspension/centrifugation in $50 \mathrm{~mm}-\mathrm{Tris} / \mathrm{HCl}$ buffer, $\mathrm{pH} 7.8$, containing $0.6 \mathrm{M}$-sucrose. The spheroplast sludge was homogenized for $45 \mathrm{~s}$ at top speed in a glass homogenizer, then a crystal of deoxyribonuclease was added and the homogenate was incubated at $23^{\circ} \mathrm{C}$ for $5 \mathrm{~min}$. The homogenizing and deoxyribonuclease treatment was repeated twice (Mowbray \& Moses, 1976). Finally, intact bacteria were removed by centrifuging at $15000 \mathrm{~g}$ for $20 \mathrm{~min}$ at $4^{\circ} \mathrm{C}$ in an MSE 18 Highspeed centrifuge.

Cross-linking with dimethylimidates. Cross-linking methods were generally based on those developed by Professor J. R. Coggins of this Department (personal communication and Coggins, 1978), but in some

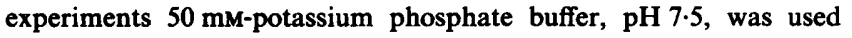
instead of TNM buffer (i.e. $50 \mathrm{mM}$-triethanolamine $/ \mathrm{HCl}$ buffer, pH 8.0, containing $0 \cdot 1 \mathrm{M}-\mathrm{NaCl}$ and $10 \mathrm{mM}-\mathrm{MgCl}_{2}$ ). Cross-linking intact bacteria with dimethylimidates used a method based on that described by Halpin et al. (1981). Exponentially growing bacteria (after about $5 \mathrm{~h}$ growth) were harvested and washed once with TNM buffer, $\mathrm{pH} 8.0$, and resuspended in the same buffer $\left(0.4 \mathrm{~g}\right.$ wet wt $\left.\mathrm{ml}^{-1}\right)$. The crosslinker $(0.1 \mathrm{M})$ was added to give a final concentration of $6 \mathrm{mM}$. The bacterial suspension was incubated for $60 \mathrm{~min}$ at $23^{\circ} \mathrm{C}$ with gentle swirling. In experiments where potassium phosphate buffer, $\mathrm{pH} 7 \cdot 5$,

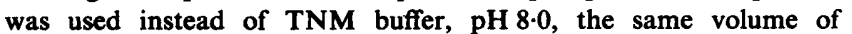
dimethylimidate solution was added every $15 \mathrm{~min}$ over the $60 \mathrm{~min}$ incubation period.

In cross-linking experiments using homogenates prepared with the French press, freshly harvested bacteria were resuspended in TNM buffer, $\mathrm{pH} \mathrm{8.0,}$, to a final concentration of $0.5 \mathrm{~g}$ wet $\mathrm{wt} \mathrm{ml}^{-1}$. An appropriate volume of $0.1 \mathrm{M}$-dimethylimidate was added to the bacterial suspension to give a final concentration of $6 \mathrm{mM}$, after which the bacterial suspension was passed through the French press. The same volume of a $0.1 \mathrm{M}$ solution of dimethylimidate was added to the resulting homogenate which was passed through the French press again. When all four passages through the French press had been completed, a further volume of $0 \cdot 1 \mathrm{M}$-dimethylimidate was added to the homogenate which was incubated at $23^{\circ} \mathrm{C}$ for $60 \mathrm{~min}$ with gentle swirling. In experiments where the bacteria were resuspended in

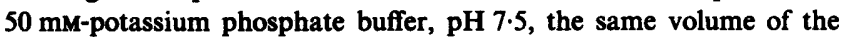
0.1 M-dimethylimidate solution was added every $15 \mathrm{~min}$ throughout the 
$60 \mathrm{~min}$ incubation period. Unbroken bacteria and debris were removed by centrifuging at $15000 \mathrm{~g}$ for $20 \mathrm{~min}$ at $4^{\circ} \mathrm{C}$ in an MSE 18 Highspeed centrifuge.

Gel-filtration chromatography. (a) Extracts prepared by ultrasonication of control and DMSI-treated $P$. putida were applied to a 1.4 litre column $(71 \mathrm{~cm}$ long $\times 5.2 \mathrm{~cm}$ diam.) of Ultrogel AcA 34 which had been equilibrated with TNM buffer, pH 8.0. Enzymes were eluted with the same buffer at a flow rate of $60 \mathrm{ml} \mathrm{h}^{-1}$. (b) Homogenates that had been prepared by French press treatment were applied to a column $(30 \mathrm{~cm}$ long $\times 0.7 \mathrm{~cm}$ diam.) of Ultrogel AcA 34 equilibrated with $0.1 \mathrm{M}$-potassium phosphate buffer, $\mathrm{pH} \mathrm{7.5}$, containing $100 \mu \mathrm{M}$-TPP, $100 \mu \mathrm{M}$-DTT, $2 \mathrm{~mm}-\mathrm{MgSO}_{4}$ and $1 \mathrm{~mm}$-EDTA. Material was eluted with the same buffer at a flow rate of $4 \mathrm{ml} \mathrm{h}^{-1}$ and fractions were collected every $7.5 \mathrm{~min}$.

High-speed centrifugation. (a) Extracts prepared from control and cross-linked bacteria were centrifuged at $105000 \mathrm{~g}$ for $1 \mathrm{~h}$ at $4{ }^{\circ} \mathrm{C}$ and the pellets were washed three times by resuspension and centrifugation. (b) In other cases, supernatants produced by disruption and centrifugation at low speed were centrifuged at $165000 \mathrm{~g}$ for $150 \mathrm{~min}$ and the high-speed pellets ('wall + membrane' fraction) were washed twice by resuspension and centrifugation under the same conditions.

Percoll density-gradient centrifugation. A stock Percoll (Pharmacia) solution was prepared by adding $18 \mathrm{ml}$ Percoll to $2 \mathrm{ml} 2.5 \mathrm{M}$-sucrose in 0.5 M-potassium phosphate buffer, $\mathrm{pH} 7.5$. A $20 \%$ (v/v) Percoll solution was obtained by making $22.2 \mathrm{ml}$ of the stock Percoll solution up to $100 \mathrm{ml}$. Sample $(1 \mathrm{ml})$ was layered onto $20 \mathrm{ml}$ of this $20 \%$ Percoll solution in a Ti60 polycarbonate centrifuge tube. The sample was then centrifuged for $30 \mathrm{~min}$ at $64000 \mathrm{~g}_{\mathrm{av}}$. after which $1 \mathrm{ml}$ fractions were collected from the top of the self-generated gradient. Density-gradient marker beads (Pharmacia) were included in each run in a separate tube to calibrate the density gradient formed.

Toluene treatment of bacteria in the presence of poly(ethylene glycol). Bacteria were treated with toluene according to the method described by Beggs \& Fewson (1977) except that buffers contained $8.5 \%$ (w/v) poly(ethylene glycol) (Matlib et al., 1977). Bacteria (3.8 ml; $0.8 \mathrm{~g}$ wet wt $\mathrm{ml}^{-1}$ ) were pipetted onto $200 \mu \mathrm{l} 4 \%(\mathrm{v} / \mathrm{v})$ toluene in ethanol. The mixtures were vortexed for $30 \mathrm{~s}$ and incubated at $27^{\circ} \mathrm{C}$ in a water-bath for $90 \mathrm{~min}$.

Enzyme assays. Enzyme activities were measured spectrophotometrically at $27^{\circ} \mathrm{C}$ using $3 \mathrm{ml}$ reaction mixtures in cuvettes with $1 \mathrm{~cm}$ lightpaths. Activities are expressed as enzyme units, where 1 unit is the amount of enzyme catalysing the conversion of $1 \mu \mathrm{mol}$ of substrate $\mathrm{min}^{-1}$. For NAD(P)-linked enzymes a change in $A_{340}$ of 2.07 was taken to correspond to the conversion of $1 \mu \mathrm{mol}$ of substrate.

$\mathrm{L}(+)$-Mandelate dehydrogenase and $\mathrm{D}(-)$-mandelate dehydrogenase activities were assayed by measuring the reduction of 2,6-dichloroindophenol at $600 \mathrm{~nm}$ in the presence of $N$-methylphenazonium methosulphate and BSA (Allison et al., 1985b). A decrease in $A_{600}$ of 7.18 units was taken to correspond to the oxidation of $1 \mu \mathrm{mol}$ of substrate at pH 7.5.

The method for measuring mandelate racemase activity was adapted from that described by Hegeman (1966). Mandelate dehydrogenase activity was assayed as for D-mandelate dehydrogenase but, in addition, a sufficient quantity of a 'wall + membrane' fraction from $A$. calcoaceticus mutant strain $\mathrm{Cl} 005$ which had been grown in complex medium supplemented with DL-mandelate was added to give non-ratelimiting amounts of $\mathrm{L}$-mandelate dehydrogenase activity. D-Mandelate $(0.1 \mathrm{ml}$ of a $12.5 \mathrm{~mm}$ solution) was added to initiate the reaction.

A new method was developed for measuring the activity of phenylglyoxylate decarboxylase. The formation of benzaldehyde was coupled to the oxidation of NADH by horse-liver alcohol dehydrogenase. The enzyme was assayed in reaction mixtures containing (total volume $3.0 \mathrm{ml}): 1 \mathrm{mmol}(2 \mathrm{ml}$ of $0.5 \mathrm{M})$ potassium phosphate buffer, pH $6.0 ; 0.5 \mu \mathrm{mol}(0.1 \mathrm{ml}$ of $5 \mathrm{mM}) \mathrm{NADH} ; 17 \mu \mathrm{g}$ of horse-liver alcohol dehydrogenase $\left(0.1 \mathrm{ml}\right.$ of a $0.5 \mathrm{mg}$ protein $\mathrm{ml}^{-1}$ solution); $200 \mathrm{nmol}$ TPP $(0.1 \mathrm{ml}$ of $2 \mathrm{mM}$ stock solution in $0.25 \mathrm{M}$-potassium phosphate buffer, pH 7.0); enzyme sample (usually $50 \mu \mathrm{l})$ and $15 \mu \mathrm{mol}(0.1 \mathrm{ml}$ of $150 \mathrm{~mm}$ ) phenylglyoxylate, adjusted to $\mathrm{pH} 6.0$, was added to initiate the reaction. The alcohol dehydrogenase was confirmed to be present in non-rate-limiting concentrations for any given sample of extract by measuring the rate of oxidation of NADH in the presence of increasing concentrations of alcohol dehydrogenase. Minus-substrate blanks were included to compensate for any NADH oxidase activity present in the samples.

Benzaldehyde dehydrogenase I activity of $A$. calcoaceticus was measured by following the reduction of NAD at $340 \mathrm{~nm}$ as described by Beggs \& Fewson (1977). NAD- and NADP-dependent benzaldehyde dehydrogenase activities of $P$. putida were measured by following the reduction of $N A D(P)$ at $340 \mathrm{~nm}$ as described by Hegeman (1966).

Catechol 1,2-dioxygenase activity was measured by following the production of cis,cis-muconate at $260 \mathrm{~nm}$ (Hegeman, 1966). An increase in $A_{260}$ of 5.6 units corresponded to the conversion of $1 \mu \mathrm{mol}$ of catechol to cis,cis-muconate.

Isocitrate dehydrogenase activity was assayed by the method of Borthwick et al. (1984) by following the reduction of NADP at $340 \mathrm{~nm}$.

NADH oxidase was measured by following the oxidation of NADH at $340 \mathrm{~nm}$ (Allison et al., 1985a).

Glutamine synthetase was assayed by the coupled procedure described by Kingdon et al. (1968), using pyruvate kinase and lactate dehydrogenase.

Preparation of antisera. (a) The recovery of $\mathrm{L}(+)$-mandelate dehydrogenase at the final stage of its purification was poor (Hoey et al., 1987) and so a modified version of the method used by Mihara \& Blobel (1980) was used to produce protein for injection. $L(+)$ Mandelate dehydrogenase was purified as described by Hoey $e t$ al. (1987) up to the gel-filtration stage. The pooled fractions from the gelfiltration column were treated with $\left(\mathrm{NH}_{4}\right)_{2} \mathrm{SO}_{4}$ to yield a $15-30 \%$ saturated fraction which was resuspended in 5 to $10 \mathrm{ml} 20 \mathrm{~mm}$ potassium phosphate buffer, $\mathrm{pH} 7.5$, containing $0.05 \%(\mathrm{w} / \mathrm{v})$ Triton $\mathrm{X}$ $100,100 \mu \mathrm{M}$-DTT and $10 \%(\mathrm{v} / \mathrm{v})$ ethanediol. The $\left(\mathrm{NH}_{4}\right)_{2} \mathrm{SO}_{4}$ fraction was subjected to electrophoresis on a $12.5 \%(w / v)$ SDS/polyacrylamide slab gel which was then stained with Coomassie Blue and destained. The band corresponding to $\mathrm{L}(+)$-mandelate dehydrogenase was cut out and the gel was washed in distilled water until the $\mathrm{pH}$ of the wash was 7.0. The gel was ground in liquid nitrogen and the powder was immediately transferred to the barrel of a $2 \mathrm{ml}$ syringe. Distilled water $(0.5 \mathrm{ml}$ approx.) was added and the sample was sonicated for $3 \times 30 \mathrm{~s}$ using the microtip of the Dawe Soniprobe (type 7332A). An equal volume of Freund's complete adjuvant (samples for boost inoculations were prepared with Freund's incomplete adjuvant) was added and the sonication was repeated. The emulsion was then loaded into $1 \mathrm{ml}$ syringes. A rabbit weighing about $4 \mathrm{~kg}$ was injected subcutaneously at several different sites with a total of $100 \mu \mathrm{g}(+)$-mandelate dehydrogenase. After 5 weeks a further $100 \mu \mathrm{g}$ was injected and another booster injection was given 2 weeks later. After a further two weeks, blood was collected from the rabbit's ear vein. Blood samples were allowed to clot at room temperature and left overnight at $4{ }^{\circ} \mathrm{C}$. The serum was pipetted off and centrifuged at $15000 \mathrm{~g}$ for $10 \mathrm{~min}$ to remove the red blood cells. Samples $(1 \mathrm{ml})$ were stored at $-20^{\circ} \mathrm{C}$. (b) Antisera against Dmandelate dehydrogenase were prepared as described by Fewson $e t$ al. (1988). (c) Antiserum was raised against phenylglyoxylate decarboxylase as described by Barrowman et al. (1986).

Immunoblotting. Cross-linked species were analysed by first subjecting them to SDS-PAGE (Laemmli, 1970) on slab gels containing $7.5 \%$ $(w / v)$ polyacrylamide and then immunoblotting them using the method described by Towbin et al. (1979) and modified by Batteiger $e t$ al. 
(1982). Bands were visualized with peroxidase conjugate/chloronaphthol (Fewson et al., 1988).

Immunoprecipitation studies. Appropriate concentrations of extracts $(100 \mu 1)$ were incubated with undiluted antisera $(100 \mu 1)$, or with normal rabbit serum or buffer as controls, for $1 \mathrm{~h}$ at $23^{\circ} \mathrm{C}$. Protein ASepharose $(100 \mu \mathrm{l})$ was added and the samples were incubated for a further hour at $23^{\circ} \mathrm{C}$ before immunocomplexes were precipitated by centrifuging for $5 \mathrm{~min}$ in an Eppendorf 3200 centrifuge.

Analytical methods. Protein was estimated by the Lowry procedure and BSA was used as the standard.

\section{Results and Discussion}

\section{Cross-linking intact P. putida with DMSI}

$P$. putida was treated with DMSI in the presence of TNM

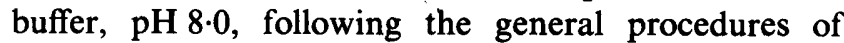
Halpin et al. (1981). After disrupting the bacteria by ultrasonication, the extracts were analysed by high-speed centrifugation (Table 1). Catechol 1,2-oxygenase was used as a control 'soluble' enzyme from a related part of metabolism and isocitrate dehydrogenase and glutamine synthetase were used as control 'soluble' enzymes from unrelated parts of metabolism. Furthermore, glutamine synthetase served as a control enzyme with a high $M_{r}$ (600000) whereas isocitrate dehydrogenase was an example of an enzyme with a lower $M_{\mathrm{r}}(100000)$. Halpin et al. (1981) also used glutamine synthetase as a control enzyme but they assayed cis,cis-muconate lactonizing enzyme instead of catechol 1,2-oxygenase.

In general, DMSI did not affect the total specific activities of the enzymes, although $L(+)$-mandelate dehydrogenase (which is a membrane-bound enzyme) was slightly inhibited (Table 1). There was a 5- to 50-fold increase in the specific activities of the 'soluble' enzymes of the mandelate pathway present in the high-speed pellet after DMSI treatment. However, this was not a specific effect since the specific activities of catechol 1,2oxygenase, isocitrate dehydrogenase and glutamine synthetase in the pellet were also increased by about the same extent (Table 1). No increases in the specific activities of the enzymes in the high-speed pellets were observed after DMSI treatment of stationary phase bacteria. The results in Table 1 are very similar to those reported by Halpin et al. (1981) who also found increases in the specific activities of control enzymes in the high speed pellets. Unfortunately, Halpin et al. (1981) did not express their results in terms of total percentage of enzyme activity nor does the information in their paper allow the percentages to be calculated. However, when the results from the present experiments are expressed in this way (Table 1) it can be seen that the proportion of the 'soluble' mandelate enzymes recovered in the pellet fraction after DMSI treatment $(2$ to $10 \%)$ is very small in relation to the proportion of $\mathrm{L}(+)$-mandelate dehydrogenase $(97 \%)$ present.

Halpin et al. (1981) also analysed sonic extracts from control and DMSI-treated $P$. putida by gel filtration through Ultrogel AcA 22. They suggested that there was an 'all-or-nothing' trapping of the high- $M_{\mathrm{r}}$ complex of protein since there was little evidence of dimers, trimers or tetramers of the individual enzymes and so they concluded that the cross-linking was not completely random. We did similar experiments, but used Ultrogel

\section{Table 1. Cross-linking P. putida with DMSI}

$P$. putida was grown in minimal mandelate medium, harvested in late exponential phase and treated with DMSI in the presence

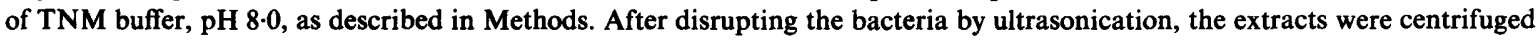
at $105000 \mathrm{~g}_{\mathrm{av}}$ for $60 \mathrm{~min}$ and the high-speed pellets so formed were washed three times by resuspension/centrifugation. The pellets, supernatants and washes were assayed for enzyme activity so that the results could be expressed in terms of the percentage of the total enzyme activity recovered. The 'total specific activities' were derived from the addition of the enzyme units and protein, respectively, recovered in the pellet, supernatant and washes of each sample. ND, Not detectable.

\begin{tabular}{|c|c|c|c|c|c|c|}
\hline \multirow[b]{2}{*}{ Enzyme } & \multicolumn{2}{|c|}{$\begin{array}{c}\text { Total specific } \\
\text { activity } \\
\left.\text { [munits (mg protein) })^{-1}\right]\end{array}$} & \multicolumn{2}{|c|}{$\begin{array}{c}\text { Specific activity } \\
\text { in pellet } \\
\left.\text { [munits (mg protein })^{-1}\right]\end{array}$} & \multicolumn{2}{|c|}{$\begin{array}{c}\text { Activity recovered } \\
\text { in pellet } \\
(\%)\end{array}$} \\
\hline & Control & $\begin{array}{l}\text { DMSI- } \\
\text { treated }\end{array}$ & Control & $\begin{array}{l}\text { DMSI- } \\
\text { treated }\end{array}$ & Control & $\begin{array}{l}\text { DMSI- } \\
\text { treated }\end{array}$ \\
\hline $\mathbf{L}(+)$-Mandelate dehydrogenase & 309 & 247 & 661 & 622 & 95 & 97 \\
\hline Mandelate racemase & 433 & 408 & $2 \cdot 2$ & 100 & $0 \cdot 2$ & $9 \cdot 4$ \\
\hline Phenylglyoxylate decarboxylase & 215 & 248 & $2 \cdot 9$ & $13 \cdot 3$ & $0 \cdot 6$ & $2 \cdot 1$ \\
\hline NAD-linked benzaldehyde dehydrogenase & 79 & 76 & ND & ND & ND & ND \\
\hline NADP-linked benzaldehyde dehydrogenase & 49 & 56 & 0.8 & $7 \cdot 3$ & $0 \cdot 7$ & 5 \\
\hline Catechol 1,2 -oxygenase & 498 & 499 & $2 \cdot 7$ & 40 & 0.2 & $3 \cdot 1$ \\
\hline Isocitrate dehydrogenase & 524 & 412 & $2 \cdot 9$ & 33 & $0 \cdot 3$ & $3 \cdot 1$ \\
\hline Glutamine synthetase & 25 & 33 & $2 \cdot 3$ & 18 & $4 \cdot 2$ & 22 \\
\hline Protein & - & - & - & - & 45 & 38 \\
\hline
\end{tabular}


AcA 34 because of its higher resolving power. All the 'soluble' enzymes assayed (mandelate racemase, phenylglyoxylate decarboxylase, NADP-linked benzaldehyde dehydrogenase, catechol 1,2-oxygenase, isocitrate dehydrogenase and glutamine synthetase), except NADlinked benzaldehyde dehydrogenase, showed higher- $M_{r}$ species after DMSI treatment. In each case one of the high- $M_{\mathrm{r}}$ species co-eluted with $\mathrm{L}(+)$-mandelate dehydrogenase. However, with the exception of NAD-linked benzaldehyde dehydrogenase, the enzymes eluted over a broad range of $M_{\mathrm{r}}$ values after DMSI treatment. In other words, not only were there enzyme activities in the veryhigh- $M_{\mathrm{r}}$ fractions, but there were also intermediate- $M_{\mathrm{r}}$ species smaller than the fraction containing most of the $\mathbf{L}(+)$-mandelate dehydrogenase activity but larger than the untreated enzymes.

\section{Cross-linking intact A. calcoaceticus}

Although the results from the experiments with $P$. putida suggested that only non-specific cross-linking had occurred, a series of experiments on $A$. calcoaceticus was done in the hope that cross-linking of a specific mandelate complex could be obtained.

A. calcoaceticus mutant strain $\mathrm{C} 1005$ was treated with DMSI, disrupted by ultrasonication and the homogenate analysed by high-speed centrifugation. The results obtained for A. calcoaceticus (Table 2) were similar to those for $P$. putida (Table 1). L(+)-Mandelate dehydrogenase (total specific activity) was again inhibited by the DMSI treatment. There was an increase of about 10-fold in the specific activity of phenylglyoxylate decarboxylase recovered in the pellet but this corresponded to only $1 \%$ of the total activity. As with $P$. putida, the specific activities of the 'soluble' control enzymes in the high- speed pellets were also increased (Table 2). Again as for $P$. putida, the increases in activities in the pellet fractions after DMSI treatment were observed only in bacteria that had been growing exponentially.

The following experiments all failed to provide any evidence for the cross-linking of a specific mandelate complex. (a) Different strains of $A$. calcoaceticus (wildtype strain 8250, mutant strains $\mathrm{C} 1219$ and $\mathrm{C1123}$ ) all gave similar results to those obtained for mutant strain C1005. (b) Different dimethylimidates [structures $\left.R-\left(\mathrm{CH}_{2}\right)_{n}-\mathrm{R}\right]$, i.e. dimethylmalonimidate $(n=1)$, dimethylsuccinimidate $(n=2)$, dimethylglutarimidate $(n=3)$, dimethyladipimidate $(n=4)$, DMPI $(n=5)$ and DMSI $(n=6)$, all of which cross-link lysine residues, were studied. In addition, the effect of phenylene dimaleimide which cross-links thiol groups was also investigated. No specific cross-linking was observed after treatment with any of these reagents and in all cases $\mathrm{L}(+)$-mandelate dehydrogenase (total specific activity) was inhibited. Slightly more of all the 'soluble' enzymes (about $3 \%$ in the case of phenylglyoxylate decarboxylase) were recovered in the pellet after cross-linking with DMPI than with any of the other cross-linkers. (c) Slightly more cross-linking (up to $6 \%$ phenylglyoxylate decarboxylase associated with the pellet) was observed after bacteria had been made permeable with toluene in the presence of $8.5 \%(\mathrm{w} / \mathrm{v})$ poly(ethylene glycol). A 3- to 20 -fold increase in the specific activities of the 'soluble' enzymes in the pellet was also observed in stationary phase bacteria after toluene/poly(ethylene glycol) treatment. However, these effects were seen for the control enzymes as well as for the mandelate enzymes. $(d)$ In some experiments bacteria were treated with toluene/ poly(ethylene glycol) and then cofactors and substrates of the mandelate enzymes were added. However, there was

\section{Table 2. Cross-linking A. calcoaceticus mutant strain C1005 with DMSI}

A. calcoaceticus mutant strain C1005, grown in complex medium supplemented with DL-mandelate, was harvested in late exponen-

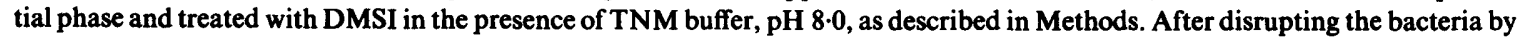
ultrasonication, the extracts were centrifuged at $105000 \mathrm{gav}_{\mathrm{av}}$ for $60 \mathrm{~min}$ and the pellets were washed three times by resuspension/ centrifugation. All the fractions were assayed for enzyme activity. ND, Not detectable.

\begin{tabular}{|c|c|c|c|c|c|c|}
\hline \multirow[b]{2}{*}{ Enzyme } & \multicolumn{2}{|c|}{$\begin{array}{c}\text { Total specific } \\
\text { activity } \\
\text { [munits (mg protein) }{ }^{-1} \text { ] }\end{array}$} & \multicolumn{2}{|c|}{$\begin{array}{c}\text { Specific activity } \\
\text { in pellet } \\
\text { [munits (mg protein) })^{-1} \text { ] }\end{array}$} & \multicolumn{2}{|c|}{$\begin{array}{c}\text { Activity recovered } \\
\text { in pellet } \\
(\%)\end{array}$} \\
\hline & Control & $\begin{array}{l}\text { DMSI- } \\
\text { treated }\end{array}$ & Control & $\begin{array}{l}\text { DMSI- } \\
\text { treated }\end{array}$ & Control & $\begin{array}{l}\text { DMSI- } \\
\text { treated }\end{array}$ \\
\hline 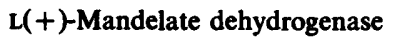 & 90 & 63 & 184 & 200 & 57 & 63 \\
\hline Phenylglyoxylate decarboxylase & 166 & 166 & 0.7 & $8 \cdot 0$ & 0.11 & $1 \cdot 0$ \\
\hline Benzaldehyde dehydrogenase I & 86 & 79 & ND & ND & ND & ND \\
\hline Catechol 1,2-oxygenase & 82 & 175 & 12 & 49 & $4 \cdot 2$ & 5.6 \\
\hline Isocitrate dehydrogenase & 157 & 166 & 6 & 27 & $3 \cdot \overline{5}$ & $3 \cdot 2$ \\
\hline Glutamine sỳnthetäse & 53 & 63 & 10 & 28 & $5 \cdot 2$ & 8.8 \\
\hline Protein & - & - & - & - & 18 & 20 \\
\hline
\end{tabular}


still no indication for specific cross-linking of a mandelate complex.

\section{Enzyme distribution after disruption of A. calcoaceticus by different methods}

Since no specific cross-linking of the mandelate enzymes was observed, we investigated alternative methods of examining enzyme interactions and first checked the effects of different methods of disruption on the distribution of enzyme activities in fractions obtained by high-speed centrifugation $\left(165000 \mathrm{~g}_{\mathrm{av}}, 150 \mathrm{~min}\right)$.

(a) Ultrasonic disruption. When bacteria were disrupted by ultrasonication, 50 to $60 \%$ of the $\mathrm{L}(+)$-mandelate dehydrogenase was recovered in the pellet fraction whereas only $4 \%$ (or less) of phenylglyoxylate decarboxylase, benzaldehyde dehydrogenase I, catechol 1,2-oxygenase and isocitrate dehydrogenase and about $30 \%$ of the glutamine synthetase were present in this fraction.

(b) Disruption by lysozyme treatment. After bacteria had been treated with lysozyme as described in Methods, as much as $95 \%$ of the $\mathrm{L}(+)$-mandelate dehydrogenase, but only 0 to $17 \%$ of the 'soluble' enzymes phenylglyoxylate decarboxylase, benzaldehyde dehydrogenase I, catechol 1,2-oxygenase and isocitrate dehydrogenase were recovered in the pellet fraction along with $30 \%$ of glutamine synthetase.

(c) Use of the French pressure cell. When bacteria had been passed through the French press once or twice, 97\% of the $\mathrm{L}(+)$-mandelate dehydrogenase, 40 to $55 \%$ of phenylglyoxylate decarboxylase, 3 to $15 \%$ of benzaldehyde dehydrogenase I, catechol 1,2-oxygenase and isocitrate dehydrogenase and $40 \%$ of glutamine synthetase were recovered in the pellet fraction, whereas when bacteria had been passed through the French press three or four times, $95 \%$ of the $\mathrm{L}(+)$-mandelate dehydrogenase but only $20 \%$ of phenylglyoxylate decarboxylase still remained in the pellet with 3 to $8 \%$ of the benzaldehyde dehydrogenase I, catechol 1,2-oxygenase and isocitrate dehydrogenase and $40 \%$ of glutamine synthetase. The presence of deoxyribonuclease or $\mathbf{M g}^{2+}$ did not alter these enzyme distributions. About 30 to $40 \%$ of the glutamine synthetase sedimented, irrespective of the method of disruption and this presumably illustrates the behaviour of a high- $M_{\mathrm{r}}$ protein under the conditions of centrifugation used.

The protein concentration of French press homogenates was varied by suspending bacteria to different concentrations $\left(0.03\right.$ to $1.0 \mathrm{~g}$ wet wt ml $\left.{ }^{-1}\right)$. This had little effect on the proportions ( 86 to $98 \%$ ) of $L(+)$-mandelate dehydrogenase and NADH oxidase (another 'control' enzyme, this time one that is membrane-bound) recovered in the pellet. However, there was a substantial effect on the amount of phenylglyoxylate decarboxylase recov- ered in the pellet; at high protein concentration, $92 \%$ of the phenylglyoxylate decarboxylase was recovered in the pellet fraction, whereas at low protein concentration only $22 \%$ was recovered in this fraction. The distribution of the other enzymes also varied somewhat with the protein concentration of the homogenate (from highest to lowest protein concentration): benzaldehyde dehydrogenase I, 56 to $9 \%$; isocitrate dehydrogenase, 58 to $34 \%$; catechol 1,2-oxygenase 30 to $9 \%$; glutamine synthetase 54 to $32 \%$; protein, 50 to $30 \%$. These results may perhaps illustrate an interaction of phenylglyoxylate decarboxylase with the membrane, and therefore possibly, but not necessarily, with $\mathrm{L}(+)$-mandelate dehydrogenase, at high protein concentrations. If the amount of isocitrate dehydrogenase $(58 \%)$ recovered in the pellet fraction is taken as a measure of non-specific binding, then it would be possible to argue that $34 \%(92 \%$ minus $58 \%)$ of the total phenylglyoxylate decarboxylase interacts (at high protein concentration) with the membrane fraction. However, it would be difficult to use these data as evidence for the existence of a mandelate complex in view of the results for catechol 1,2-oxygenase and isocitrate dehydrogenase.

\section{Buffer conditions}

Conditions commonly used to dissociate extrinsic membrane proteins (e.g. $0.2 \mathrm{M}-\mathrm{NaCl}, 0.5 \mathrm{M}-\mathrm{KCl}, 0.2 \mathrm{M}$ $\mathrm{MgCl}_{2}, 0.02 \mathrm{M}$-EDTA, 0.02 M-EGTA, buffers at pH 6.0 and 8.5 ) were used to try to achieve a differential release of isocitrate dehydrogenase from high-speed pellets prepared by centrifugation of homogenates produced in the French pressure cell while leaving phenylglyoxylate decarboxylase associated with the pellet. In all cases, however, where isocitrate dehydrogenase was washed off, phenylglyoxylate decarboxylase was also washed from the pellets although there was always more phenylglyoxylate decarboxylase than isocitrate dehydrogenase recovered in the membrane fraction.

\section{Percoll-gradient centrifugation and gel-filtration chromatography}

French press homogenates were analysed by Percoll density-gradient centrifugation and by gel-filtration chromatography. No co-elution of phenylglyoxylate decarboxylase with $\mathrm{L}(+)$-mandelate dehydrogenase was observed even in the presence of high protein concentrations (30 mg BSA ml $\left.{ }^{-1}\right)$ or in the presence of $20 \%(\mathrm{v} / \mathrm{v})$ glycerol.

\section{Cross-linking French press homogenates with dimethylimidates}

Since such a high percentage of phenylglyoxylate decarboxylase could be associated with the membrane 
fraction after disruption of the bacteria in the French pressure cell, it was thought that a putative specific complex might be stabilized by cross-linking the French press homogenate. The earlier cross-linking experiments using intact bacteria were done in the presence of TNM buffer, $\mathrm{pH} 8.0$, in order to allow direct comparison with the experiments of Halpin et al. (1981). However, the phenylglyoxylate decarboxylase tetramer dissociates at this high $\mathrm{pH}$ and so a method for cross-linking with the dimethylimidates at a lower $\mathrm{pH}$ was developed (see Methods). Freshly harvested $\boldsymbol{A}$. calcoaceticus mutant strain $\mathrm{C} 1005$ which had been grown in complex medium supplemented with DL-mandelate was treated with DMSI and DMPI at pH 7.5 during the preparation of French press homogenates, as decribed in Methods. After incubating with the cross-linker a 'wall + membrane' fraction was prepared from the homogenate. There was no increase in the proportion of phenylglyoxylate decarboxylase recovered in the pellet fraction after treatment with DMSI or DMPI. When the pellets were washed by resuspending to half the original volume of the homogenate, about $70 \%$ of the total phenylglyoxylate decarboxylase and $40 \%$ of the isocitrate dehydrogenase were recovered in the high-speed pellets of control and treated samples alike. When the pellets were washed by diluting to 2.5 times the original volume, $36 \%$ of the phenylglyoxylate decarboxylase and $6 \%$ of the isocitrate dehydrogenase remained associated with the membrane fractions of control samples, and $44 \%$ of the phenylglyoxylate decarboxylase and $6 \%$ of the isocitrate dehydrogenase were recovered in the pellet fraction of the cross-linked homogenate.

\section{Analysis of cross-linked French press homogenates by immunoblotting}

Control and cross-linked homogenates were analysed by immunoblotting with anti-L(+)-mandelate dehydrogenase, anti- $\mathrm{D}(-)$-mandelate dehydrogenase and antiphenylglyoxylate decarboxylase in order to see if there were any bands that contained two or three of these proteins. In the control (uncross-linked) samples there were bands corresponding to $\mathrm{L}(+)$-mandelate dehydrogenase, $D(-)$-mandelate dehydrogenase or phenylglyoxylate decarboxylase whereas in the cross-linked samples there were bands with high apparent $M_{\mathrm{r}}$ values. In all cases DMSI and DMPI gave similar results. In the anti$\mathrm{L}(+)$-mandelate dehydrogenase blot there were bands with apparent $M_{\mathrm{r}}$ values of 140000 (this band was not always detected and sometimes appeared in the control sample), 100000 and 40000 [equivalent to $L(+)-$ mandelate dehydrogenase; Hoey et al. (1987)]. In the anti-D(-)-mandelate dehydrogenase blot, there was a band with an apparent $M_{\mathrm{r}}$ value of 66000 [equivalent to $\mathrm{D}(-)$-mandelate dehydrogenase; Allison et al. (1985b)] in the control sample; however, there was no band with this $M_{\mathrm{r}}$ value in the cross-linked sample but there was one with a slightly higher $M_{\mathrm{r}}$ value (68000) which may be due to intramolecular cross-linking. In addition there was a smear in the cross-linked samples which probably indicates that $D(-)$-mandelate dehydrogenase was crosslinked to proteins of various $M_{r}$ values. In the antiphenylglyoxylate decarboxylase blot bands with apparent $M_{\mathrm{r}}$ values of $135000,120000,98000$ and 56000 (the latter being equivalent to phenylglyoxylate decarboxylase; Barrowman \& Fewson, 1985) were detected. A similar blotting pattern with anti-phenylglyoxylate decarboxylase was obtained with extracts from mutant strain C1005 [L(+)-mandelate dehydrogenase and phenylglyoxylate decarboxylase activities present] and mutant strain C1123 [D(-)-mandelate dehydrogenase and phenylglyoxylate decarboxylase activities present]. Comparison of the native $M_{\mathrm{r}}$ value obtained by gel filtration and the monomeric $M_{\mathrm{r}}$ obtained by SDS-PAGE indicated that phenylglyoxylate decarboxylase is a tetramer (Barrowman \& Fewson, 1985). However, there was no evidence for trimers or tetramers of phenylglyoxylate decarboxylase being formed on cross-linking although the band with an apparent $M_{\mathrm{r}}$ of 120000 may be a dimer. Cross-linking experiments were also done using mutant strain $\mathrm{C} 1408$ which has no mandelate dehydrogenase and similar immunoblots were obtained with anti-phenylglyoxylate decarboxylase indicating that whatever phenylglyoxylate decarboxylase was crosslinked to, it was not $\mathrm{L}(+)$-mandelate dehydrogenase.

The crucial observation from these experiments was that there was no single band that reacted with two or three antisera; in other words no material was detected that contained more than one of the enzymes.

\section{Immunoprecipitation of French press homogenates}

French press homogenates from mutant strains C1005 and $\mathrm{C} 1219$ were immunoprecipitated with anti-D(-)mandelate dehydrogenase and anti-phenylglyoxylate decarboxylase to see if precipitation of one enzyme by its specific antiserum resulted in the co-precipitation of a second or third (presumably associated) enzyme. Only $27 \%$ of the $\mathrm{D}(-)$-mandelate dehydrogenase and 0 to $5 \%$ of the phenylglyoxylate decarboxylase remained in the supernatant after incubating extracts with anti-D(-)mandelate dehydrogenase and anti-phenylglyoxylate decarboxylase respectively. Anti-phenylglyoxylate decarboxylase did not precipitate either $L(+)$ - or $D(-)$ mandelate dehydrogenase. However, there was a small co-precipitation ( 7 to $24 \%$ ) of phenylglyoxylate decarboxylase [but not $\mathrm{L}(+)$-mandelate dehydrogenase] by 
anti-D(-)-mandelate dehydrogenase, presumably because when $D(-)$-mandelate dehydrogenase is precipitated it takes with it, being a membrane-bound enzyme, some of those membrane components with which phenylglyoxylate decarboxylase appears to associate.

\section{Conclusions}

In their work with the mandelate enzymes of $\boldsymbol{P}$. putida, Halpin et al. (1981) were careful not to conclude that they had provided evidence for the existence of a specific mandelate complex. They did not rule out the possibility that the enzymes were not complexed to each but rather were individually cross-linked to cellular components of high $M_{\mathrm{r}}$. Our results support the latter suggestion. The chief conclusions that we draw from this work are as follows. (a) Cross-linking of proteins within intact $\boldsymbol{A}$. calcoaceticus and $P$. putida can be achieved, especially if adequate attention is paid to the physiological state of the cells at harvesting and to the conditions (including if necessary permeabilizing agents) used during the crosslinking procedure. (b) There is no convincing evidence that the mandelate enzymes of either $A$. calcoaceticus or $P$. putida exist as a specific, isolable complex. The present work was not intended to address the question as to whether substrate channeling or other possible consequences of enzyme interactions might occur during mandelate metabolism. (c) Phenylglyoxylate decarboxylase shows some inclination to associate with an unidentified component of the cytoplasmic membrane.

The outcome of these experiments has been largely negative but this does not exclude the possibility that other experimental approaches will unambiguously demonstrate the existence of a mandelate complex.

Parts of this work were supported by a grant from the Science and Engineering Research Council.

\section{References}

Allison, N., O'Donnell, M. J., Hoey, M. E. \& Fewson, C. A. $(1985 a)$. Membrane-bound lactate dehydrogenases and mandelate dehydrogenases of Acinetobacter calcoaceticus. Location and regulation of expression. Biochemical Journal 227, 753-757.

Allison, N., O'DONNell, M. J. \& Fewson, C. A. (1985b). Membranebound lactate dehydrogenases and mandelate dehydrogenases of Acinetobacter calcoaceticus. Purification and properties. Biochemical Journal 231, 407-416.
Barrowman, M. M. \& Fewson, C. A. (1985). Phenylglyoxylate decarboxylase and phenylpyruvate decarboxylase from Acinetobacter calcoaceticus. Current Microbiology 12, 235-240.

Barrowman, M. M., Harnett, W., Scott, A. J., Fewson, C. A. \& KUSEL, J. R. (1986). Immunological comparison of microbial TPPdependent non-oxidative $\alpha$-keto acid decarboxylases. FEMS Microbiology Letters 34, 57-60.

Batteiger, B., Newhall, V. W. J. \& Jones, R. B. (1982). The use of Tween 20 as a blocking agent in the immunological detection of proteins transferred to nitrocellulose membranes. Journal of Immunological Methods 55, 297-307.

BEGGS, J. D. \& FEwSON, C. A. (1977). Regulation of synthesis of benzyl alcohol dehydrogenase in Acinetobacter calcoaceticus NCIB8250. Journal of General Microbiology 103, 127-140.

Borthwick, A. C., Holms, W. H. \& Nimmo, H. G. (1984). Isolation of active and inactive forms of isocitrate dehydrogenase from Escherichia coli ML308. European Journal of Biochemistry 141, 393-400.

Chalmers, R. M. \& Fewson, C. A. (1988). Quantitative immunoblotting in the study of bacterial evolution. Biochemical Society Transactions 16, 153-154.

Coggins, J. R. (1978). The use of bis(imido esters) in the study of multisubunit proteins. In Theory and Practice of Affinity Techniques, pp. 89-112. Edited by P. V. Sunderaman \& F. Eckstein. New York: Academic Press.

Fewson, C. A. (1988). Microbial metabolism of mandelate: a microcosm of diversity. FEMS. Microbiology Reviews 54, 85-110.

Fewson, C. A., Allison, N., Hamilton, I. D., Jardine, J. \& ScotT, A. J. (1988). Comparison of mandelate dehydrogenases from various strains of Acinetobacter calcoaceticus: similarity of natural and 'evolved' forms. Journal of General Microbiology 134, 967-974.

Halpin, R. A., Hegeman, G. D. \& Kenyon, G. L. (1981). Carbon-13 nuclear magnetic resonance studies of mandelate metabolism in whole bacterial cells and in isolated, in vivo cross-linked enzyme complexes. Biochemistry 20, 1525-1533.

Hegeman, G. D. (1966). Synthesis of the enzymes of the mandelate pathway by Pseudomonas putida. Synthesis of enzymes by the wild type. Journal of Bacteriology 91, 1140-1154.

Hoey, M. E., Allison, N., Scott, A. J. \& Fewson, C. A. (1987). Purification and properties of L-mandelate dehydrogenase and comparison with other membrane-bound dehydrogenases from Acinetobacter calcoaceticus. Biochemical Journal 248, 871-876.

Kingdon, H. S., Hubbard, J. S. \& Stadtman, E. R. (1968). Regulation of glutamine synthetase. XI. The nature and implication of a lag phase in the Escherichia coli glutamine synthetase reaction. Biochemistry 7, 2136-2142.

LAEMMLI, U. K. (1970). Cleavage of structural proteins during the assembly of the head of bacteriophage T4. Nature, London 227, 680685.

Matlib, M. A., Shannon, W. A. \& Srere, P. A. (1977). Measurement of matrix enzyme activity in isolated mitochondria made permeable with toluene. Archives of Biochemistry and Biophysics 178, 396-407.

MiHARA, K. \& BLOBEL, G. (1980). The four cytoplasmically made subunits of yeast mitochondrial cytochrome c oxidase are synthesized individually and not as a polyprotein. Proceedings of the National Academy of Sciences of the United States of America 77, 4160-4164.

Mowbray, J. \& Moses, V. (1976). The tentative identification in Escherichia coli of a multienzyme complex with glycolytic activity. European Journal of Biochemistry 66, 25-36.

Towbin, H., Stakhelin, T. \& GoRDON, J. (1979). Electrophoretic transfer of proteins from polyacrylamide gels to nitrocellulose sheets: procedure and some applications. Proceedings of the National Academy of Sciences of the United States of America 76, 4350-4354. 